\title{
Performans Of Quail (Coturnix-Coturnix Javonica) Fed With Sauropus Androgynus In The Rasion
}

\author{
Rahman Dalimunthe ${ }^{1}$, Aisyah Nurmi ${ }^{2}$, Annur Rasyidah ${ }^{3}$, Risdawati br Ginting ${ }^{4}$ \\ ${ }^{1}$ Alumni Fakultas Peternakan Program Studi Peternakan Universitas Muhammadiyah \\ Tapanuli Selatan, \\ ${ }^{2}$ Dosen Program Studi Peternakan Fakultas Peternakan Universitas Muhammadiyah \\ Tapanuli Selatan, e-mail : aisyah.nurmi@um-tapsel.ac.id \\ ${ }^{3}$.Staf KPU Kabupaten Tapanuli Selatan \\ ${ }^{4}$ Dosen Program Studi Peternakan Fakultas Sains dan Teknologi Universitas Panca Budi \\ Medan
}

\begin{abstract}
Abstrak
Penelitian ini bertujuan untuk mengetahui manfaat pengunaan tepug daun katuk (Sauropus androgynus) terhadap pertambahan bobot badan, konsumsi ransum, konversi ransum selama 6 minggu pada level yang berbeda. Metode penelitian ini memakai rancangan acak lengkap (RAL) yang terdiri dari 4 perlakuan dan 5 ulangan. Adapun perlakuan K0 (Ransum tanpa penambahan tepung daun katuk), K1 (Ransum dengan penambahan tepung daun katuk 2,5\%), K2 (Ransum dengan penambahan tepung daun katuk 5\%) dan K3 (Ransum dengan penambahan tepung daun katuk 7,5\%) dalam ransum burung puyuh. Parameter yang diamati dalam penelitian ini adalah konsumsi ransum, pertambahan bobot badan, konversi ransum. Dari hasil penelitian yang diperoleh rataan konsumsi ransum (g) pada perlakuan K0 adalah 0.045 gram, berpengaruh sangat nyata terhadap perlakuan K1 (0.045 gram), K2 (0.043 gram), dan K3 ( 0.045). Rataan pertambahan bobot badan (g) selama penelitian terhadap perlakuan K0 sebesar 2.797 berpengaruh tidak nyata terhadap perlakuan K1 (3.136 gram), K2 (2.992 gram), dan K3 (3.170 gram). Rataan konversi ransum selama penelitian K0 adalah 1.680 berpengaruh tidak nyata terhadap perlakuan K1 (1.460 gram), K2 (1.470 gram), K3 (1.440 gram). Kesimpulan dari penelitian adalah tepung daun katuk dapat diberikan sampai level $7.5 \%$ sebagai pakan alternatif dan feed aditif.
\end{abstract}

Key word: katuk, puyuh, konversi ransum

\section{PENDAHULUAN}

Salah satu alternatif untuk memenuhi kebutuhan masyarakat terhadap kebutuhan zat gizi tersebut adalah dengan meningkatkan produksi ternak dan sekaligus memasyarakatkan produk-produknya yang berupa daging telur dan susu. Burung puyuh merupakan salah satu aneka ternak yang sangat cocok untuk dikembangkan walaupun di pelihara di pekarangan yang sempit dan penduduk yang begitu padat dan pendapatan rendahpun dapat memenuhi kebutuhan akan protein hewani dalam waktu singkat.

Di dalam pemenuhan protein yang tinggi di dalam ransum sering mendapat kendala dalam perolehannya, sebab yang mengandung nilai protein yang tinggi akan memiliki biaya yang mahal. Tingginya biaya pakan merupakan faktor utama yang menghambat perkembangan 
peternakan dimana biaya pakan bisa mencapai $70 \%$ dari biaya produksi. Usaha yang dilakukan untuk mengurangi biaya tersebut dengan mencari bahan pengganti pakan alternatif, dimana bahan tersebut harganya lebih murah, cukup tersedia, serta tidak bersaing dengan kebutuhan manusia.Salah satu alternatif, pemecahannya adalah pemanfaatan daun katuk (Sauropus androgynus). Daun katuk adalah perdu menahun yang sering dijumpai di Asia Tenggara. Sayuran ini dikonsumsi secara luas di Indonesia, khususnya di Kalimantan, dan seluruh wilayah India. Semak tahunan ini memiliki adaptasi tropika dan subtropika dan produktif sepanjang tahun, walaupun tanaman cenderung agak dominan pada cuaca dingin. (Bidura,candrawatidan sumardani, 2007).

Tabel 1.7 Komposisi nutrisi daun katuk

\begin{tabular}{ll}
\hline Komponen gizi & \multicolumn{1}{c}{ Kadar } \\
\hline Energi(Kkal) & 59 \\
Protein (g) & $4,8-6,4$ \\
Lemak (g) & 1,0 \\
Karbohidrat (g) & $9,9-11,0$ \\
Serat (g) & 1,5 \\
Abu (g) & 1,7 \\
Kalsium (mg) & 204 \\
Fosfor (mg) & 83 \\
Besi (mg) & $2,7-3,5$ \\
Vitamin C (mg) & $164-239$ \\
Air (g) & 81 \\
\hline Sumber Nugraha (2008)
\end{tabular}

Sumber: Nugraha (2008).

Penelitian ini bertujuan untuk mengetahui pengaruh pemberian tepung daun katuk (Sauropus androgynus) dalam ransum terhadap performans (pertambahan bobot badan, konsumsi ransum, konversi ransum) burung puyuh (Coturnix coturnix javonica). Diharapkan dari hasil penelitian ini dapat menjadi pedoman peternak dalam menyusun ransum burung puyuh.

\section{MATERI DAN METODE}

\section{Lokasi penelitian}

Penelitian dilaksanakan di kandang aneka ternak (MFE) Fakultas Peternakan Universitas Muhammadiyah Tapanuli Selatan Padangsidimpuan selama 8 minggu.

\section{Populasi dan sampel}

Ternak yang digunakan adalah Burung Puyuh umur 1 hari DOQ (Day Old Quail/ anak burung puyuh) sebanyak 100 ekor tanpa membedakan jenis kelamin (unsexing), sampel diambil dari 
populasi burung puyuh yang diperoleh dari poultry shop, dilakukan pengacakan dan di tempatkan 5 ekor setiap petak dan diberi tanda sesuai perlakuan.

\section{Variabel Penelitian}

\section{Konsumsi ransum}

Konsumsi ransum dihitung setiap minggu berdasarkan selisih antara jumlah ransum yang diberikan dengan sisa ransum dan estimasi 5\%-7\% ransum yang terbuang.

\section{Pertambahan Bobot Badan Harian}

Bobot badan ditimbang setiap minggu sekali dengan menggunakan timbangan. Penghitungan bobot badan dilakukan hingga akhir percobaan untuk dihitung pertambahan bobot badan harian.

Penghitungan pertambahan bobot badan harian adalah sebagai berikut :

$\mathrm{PBB}=\underline{((\mathrm{BB} 2-\mathrm{BB} 1)+(\mathrm{BB} 3-\mathrm{BB} 2)+\ldots .(\mathrm{BBi}-\mathrm{BB}(\mathrm{i}-1)}$ i

Keterangan : i adalah frekuensi penimbangan/jumlah penimbangan yang dilakukan selama penelitian berlangsung.

\section{Konversi Ransum}

Konversi ransum dihitung berdasarkan perbandingan jumlah ransum yang dikonsumsi dengan pertambahan bobot badan selama penelitian, dengan rumus:

$\mathrm{KR}=\underline{\text { Konsumsi Ransum (gram) }}$

Pertambahan bobot badan (gram)

\section{Rancangan Penelitian}

Rancangan penelitian yang digunakan adalah Rancangan Acak Lengkap (RAL) dengan jumlah perlakuan $(\mathrm{T})=4$, ulangan $(\mathrm{n})=5$ Adapun susunan perlakuan ransum adalah sebagai berikut :

K0 : Ransum tanpa penambahan tepung daun katuk

K1 : Ransum dengan penambahan tepung daun katuk 2, 5\%

K2 : Ransum dengan penambahan tepung daun katuk $5 \%$

K3 : Ransum dengan penambahan tepung daun katuk 7, 5\%

\section{Ransum}


Pencampuran ransum dilakukan setiap minggu sesuai perlakuan. Ransum penelitian yang digunakan terdiri dari bungkil kelapa, bungkil inti sawit, tepung ikan, tepung jagung, dedak padi, tepung daun katuk, dan mineral diberikan sesuai perlakuan.

\section{Pembuatan Tepung Daun Katuk}

Pembuatan Tepung Daun Katuk yaitu daun katuk segar dikeringkan dalam oven dengan suhu $40-50^{\circ} \mathrm{C}$ selama 72 jam. Setelah itu daun katuk kering diperkecil partikelnya (diremas dengan tangan) agar saat perendaman daya serapnya lebih tinggi. Tepung yang diperoleh kemudian direndam dalam air selama 30 menit untuk mengurangi kadar tannin, dengan perbandingan daun katuk dan air adalah 1:5. Setelah itu, tepung yang diperoleh kemudian dikeringkan pada suhu $40-50 C^{\circ}$ selama 36 jam.Setelah itu sampel dihaluskan dengan penggiling.

Tabel 2. Susunan ransum selama penelitian fase starter (0-3 minggu)

\begin{tabular}{llllll}
\hline Bahan pakan & & K0 & K1 & K2 & K3 \\
\hline T. jagung & $(\mathrm{kg})$ & 12 & 12 & 8 & 9 \\
T. katuk & $(\mathrm{kg})$ & 0 & 2,5 & 5 & 7,5 \\
B. kelapa & $(\mathrm{kg})$ & 20 & 20 & 20 & 19 \\
Dedak halus & $(\mathrm{kg})$ & 22 & 19,5 & 19 & 13,5 \\
BIS & $(\mathrm{kg})$ & 18 & 18 & 20 & 22 \\
T.ikan & $(\mathrm{kg})$ & 27 & 27 & 27 & 28 \\
Mineral & $(\mathrm{kg})$ & 1 & 1 & 1 & 1 \\
\hline \multicolumn{1}{c}{ Jumlah } & \multicolumn{7}{c}{100} & 100 & \multicolumn{1}{c}{100} & 100 \\
\hline Protein kasar & $(\%)$ & 25,2 & 25,0 & 25,0 & 25,2 \\
EM & $(\%)$ & 22775 & 2376,1 & 2436,8 & 2594,8 \\
SK & $(\%)$ & 8,0 & 7,7 & 7,7 & 7,1 \\
LK & $(\%)$ & 6,1 & 5,8 & 5,6 & 5,0 \\
Ca & $(\%)$ & 2,1 & 2,1 & 2,1 & 2,2 \\
Posfor & $(\%)$ & 1,6 & 1,5 & 1,5 & 1,5 \\
\hline
\end{tabular}

Tabel 3 Susunan ransum selama penelitian fase finisher ( $>3$ minggu)

\begin{tabular}{lccccl}
\hline Bahan pakan & & K0 & K1 & K2 & K3 \\
\hline T. jagung & $(\mathrm{kg})$ & 28 & 25,5 & 25 & 22,5 \\
T. katuk & $(\mathrm{kg})$ & 0 & 2,5 & 5 & 7,5 \\
BIS & $(\mathrm{kg})$ & 17 & 17 & 17 & 17 \\
B.kelapa & $(\mathrm{kg})$ & 17 & 17 & 17 & 17 \\
Dedak halus & $(\mathrm{kg})$ & 20 & 20 & 17 & 17 \\
T.ikan & $(\mathrm{kg})$ & 17 & 17 & 18 & 18 \\
Mineral & $(\mathrm{kg})$ & 1 & 1 & 1 & 1 \\
\hline Jumlah & & 100 & 100 & 100 & 100 \\
\hline
\end{tabular}

Protein kasar $(\%) \quad 20,1 \quad 20,0 \quad 20,2 \quad 20,1$




\begin{tabular}{lccccc} 
EM & $(\%)$ & 2445,1 & 2508,4 & 2615,8 & 2679,0 \\
SK & $(\%)$ & 7,4 & 7,3 & 7,0 & 7,0 \\
LK & $(\%)$ & 5,5 & 5,4 & 5,1 & 5,0 \\
Ca & $(\%)$ & 1,3 & 1,3 & 1,4 & 1,4 \\
Posfort & $(\%)$ & 1,2 & 1,2 & 1,3 & 1,3 \\
\hline
\end{tabular}

\section{HASIL DAN PEMBAHASAN}

\section{Konsumsi Ransum}

Konsumsi ransum merupakan kemampuan untuk menghabiskan sejumlah ransum yang diberikan.Konsumsi ransum dihitung setiap minggu berdasarkan selisih antara jumlah ransum yang diberikan dengan sisa ransum dan ransum yang terbuang.

Tabel 4. Rataan konsumsi ransum burung puyuh selama penelitian (gram/ekor/minggu)

\begin{tabular}{|c|c|c|c|c|c|c|}
\hline \multirow{2}{*}{ Ulangan } & \multicolumn{4}{|c|}{ Perlakuan } & \multirow{2}{*}{ Jumlah } & \multirow{2}{*}{ Rataan } \\
\hline & $\mathrm{KO}$ & $\mathrm{K} 1$ & K2 & K3 & & \\
\hline 1 & 0.046 & 0.046 & 0.043 & 0.045 & 0.180 & 0.045 \\
\hline 2 & 0.045 & 0.046 & 0.042 & 0.045 & 0.181 & 0.045 \\
\hline 3 & 0.045 & 0.045 & 0.043 & 0.043 & 0.178 & 0.044 \\
\hline 4 & 0.045 & 0.045 & 0.043 & 0.047 & 0.182 & 0.045 \\
\hline 5 & 0.045 & 0.044 & 0.044 & 0.046 & 0.181 & 0.045 \\
\hline Jumlah & 0.229 & 0.228 & 0.218 & 0.227 & 0.904 & 0.226 \\
\hline Rataan & $0.045^{\mathrm{A}}$ & $0.045^{\mathrm{A}}$ & $0.043^{\mathrm{A}}$ & $0.045^{\mathrm{A}}$ & 0.180 & 0.045 \\
\hline
\end{tabular}

Pada Tabel 4 memperlihatkan rataan konsumsi ransum sebesar 0.045 g/ekor/minggu dengan rataan konsumsi tertinggi terdapat pada perlakuan KO (tanpa penambahan tepung daun katuk), K1 (penambahan tepung daun katuk sebanyak 2,5\%), K3 (penambahan tepung daun katuk sebanyak 7,5\%) yaitu sebesar 0.045 g/ekor/minggu dan data terendah pada perlakuan K2(penambahan tepung daun katuk sebanyak 5\% ) yaitu sebesar 0.043 g/ekor/minggu.Konsumsi ransum hasil penelitian ini lebih rendah jika dibandingkan dengan hasil penelitian Gellip. JR. (1992) bahwa tingkat konsumsi pakan burung puyuh sebesar 109,69-135,59 g/ekor/minggu dan rata-rata konsumsi pakan burung puyuh pada penelitian Gellips. JR. (1987) berkisar antara 127,12-165,15 g/ekor/minggu.Konsumsi pakan dipengaruhi bangsa unggas, suhu lingkungan, bobot tubuh, jenis kelamin, umur, tingkat produksi telur, besar telur, aktivitas, kualitas pakan, dan tingkat stres.Suhu lingkungan di atas suhu ideal pemeliharaan unggas dapat merangsang sistem saraf dan sistem hormonal pada pusat selera makan.Kelenjar tiroid akan mensekresikan hormon tiroksin yang menyebabkan penurunan nafsu makan sehingga konsumsi pakan menurun (Mulyatini, 2010). 
Hasil analisis keragaman menunjukkan bahwa perlakuan pemberian daun katuk memberikan pengaruh yang sangat berbeda nyata terhadap konsumsi burung puyuh. Hal ini berarti perlakuan pemberian tepung daun katuk pada level yang berbeda K1 (penambahan tepung daun katuk 2.5\%), K2 (penambahan tepung daun katuk 5\%), K3 (penambahan tepung daun katuk $7.5 \%$ ) dalam ransum puyuh memberikan pengaruh jika dibandingkan dengan ransum yang tidak mengandung tepung daun katuk (K0).

Dari hasil uji BNT diatas menunjukkan bahwa puyuh yang menerima ransum dengan level yang berbeda $(2.5 \%, 5 \%$, dan $7.5 \%$ tepung daun katuk) memberikan pengaruh yang sama dengan ransum yang tidak diberi penambahan tepung daun katuk. Rendahnya konsumsi ransum burung puyuh yang menerima ransum dengan level daun katuk yang lebih banyak disebabkan oleh defisiensi Thiamin (Vitamin B 1), ransum yang defisien thiamin mempunyai pengaruh yang sangat nyata menurunkan nafsu makan. (Wahyu. J. 1992). Penyebab lain rendahnya konsumsi ransum yang mengandung tepung daun katuk pada level (5\% tepung daun katuk) adalah warna ransumnya kurang terang, seperti yang dikemukakan oleh Rasyaf (1997) ternak puyuh lebih menyukai ransum yang berwarna terang dari pada ransum yang berwarna gelap. Tidak adanya pengaruh nyata pada setiap perlakuan adalah sama formulasinya yang diketahui memiliki kandungan gizi-gizi palatabilitas yang sama. Sehingga jumlah pakan yang dikonsumsi tidak jauh berbeda pada setiap perlakuan sesuai dengan pendapat Anggorodi (1995).

\section{Pertambahan Bobot Badan}

Pengukuran pertambahan bobot badan dilakukan berdasarkan bobot badan akhir dikurangi dengan bobot badan awal persatuan waktu dalam satuan g/ekor/minggu penimbangan bobot badan dilakukan satu kali dalam seminggu.

Tabel 5 Rataan pertambahan bobot badan burung puyuh selama penelitian g/ekor/hari

\begin{tabular}{ccccccc}
\hline \multirow{2}{*}{ Ulangan } & \multicolumn{6}{c}{ Perlakuan } \\
\cline { 2 - 5 } & KO & K1 & K2 & K3 & & \multirow{2}{*}{ Rataan } \\
\hline 1 & 2.600 & 3.035 & 3.128 & 3.288 & 12.051 & 3.012 \\
2 & 3.163 & 3.448 & 3.208 & 3.120 & 12.940 & 3.235 \\
3 & 2.930 & 3.016 & 3.123 & 3.110 & 12.183 & 3.045 \\
4 & 3.170 & 3.040 & 2.811 & 3.063 & 12.085 & 3.021 \\
5 & 2.125 & 3.143 & 2.691 & 3.268 & 11.228 & 2.807 \\
\hline Jumlah & 13.988 & 15.683 & 14.963 & 15.853 & 60.488 & 3.078 \\
Rataan & $2.797^{\text {tn }}$ & $3.136^{\text {tn }}$ & $2.992^{\text {tn }}$ & $3.170^{\text {tn }}$ & 12.097 & 3.024 \\
\hline
\end{tabular}


Dari Tabel 5 terlihat bahwa rataan pertambahan bobot badan burung puyuh selama penelitian sebesar 3.024 g/ekor/minggu.Pertambahan bobot badan tertinggi terdapat pada perlakuan K3 (penambahan tepung daun katuk 7.5\%) yaitu sebesar 3.170 g/ekor/minggu dan pertambahan bobot badan terendah terdapat pada perlakuan KO (tanpa penambahan tepung daun katuk) yaitu sebesar $2.797 \mathrm{~g} /$ ekor/minggu.Pertambahan bobot badan pada penelitian ini sangat rendah jika dibandingkan dengan penelitian lain.

Pertumbuhan pada burung puyuh dapat diukur dengan menimbang beratbadan setiap periode waktu tertentu. Kecepatan pertumbuhan burung puyuh jantan dan betina dari umur satu hari sampai lima minggu, tidak berbeda. Kecepatan pertumbuhan dari 5-6 minggu, menunjukkan perbedaan yang nyata antara burung puyuh jantan dan betina (Mulyana, 1995).Pada umur empat minggu, rataan berat badan burung puyuh betina relatif lebih besar dari jantan dan perbedaan yang nyata pada umur enam minggu (Hardjosworo,1987). Berat badan burung puyuh jantan pada umur empat minggu berkisar 86,95-89,66 g dan berat badan pada populasi hasil seleksi burung puyuh jantan berkisar 109,68-122,41 g (Elly dan kinanti, 1992). Pada umur empat minggu, berat badan burungpuyuh betina pada populasi yang diseleksi berselang dari 86,97-103,33 g dan berat badan burung puyuh betina pada umur enam minggu berkisar 121,89-138,24 gram.

Analisis keragaman pemberian level tepung daun katuk memberikan pengaruh tidak nyata terhadap pertambahan bobot badan burung puyuh. Rendahnya pertambahan bobot badan pada burung puyuh disebabkan konsumsi pakan yang rendah kejadian ini diduga karena pada ransum dengan pemberian Tepung daun katuk umumnya berabu, kurang disukai oleh ternak sehingga memberi efek pada Pertambahan bobot badan yang rendah. Sejalan dengan pendapat Pitojoe (1996) bahwa konsumsi pakan yang rendah akan memberikan Pertambahan bobot badanyang kecil pula. Sebagaimana juga dikemukakan oleh Sinaga.H. (1998) kualitas protein yang dikonsumsi akan menentukan perolehan pertambahan bobot badan

\section{Konversi Ransum}

Konversi ransum dihitung berdasarkan jumlah ransum yang habis dikonsumsi dalam jangka waktu tertentu dibandingkan dengan pertambahan bobot badan pada waktu yang sama yang dihitung setiap minggunya. 
Tabel 6. Konversi ransum burung puyuh selama penelitian

\begin{tabular}{ccccccc}
\hline \multirow{2}{*}{ Ulangan } & \multicolumn{6}{c}{ Perlakuan } \\
\cline { 2 - 6 } & KO & K1 & K2 & K3 & & \multirow{2}{*}{ Rataan } \\
\hline 1 & 1.770 & 1.517 & 1.378 & 1.390 & 6.056 & 2.422 \\
2 & 1.450 & 1.349 & 1.339 & 1.464 & 5.603 & 2.241 \\
3 & 1.570 & 1.500 & 1.407 & 1.390 & 5.866 & 2.346 \\
4 & 1.450 & 1.510 & 1.563 & 1.534 & 6.057 & 2.423 \\
5 & 2.140 & 7.290 & 1.670 & 1.416 & 6.641 & 2.656 \\
\hline Jumlah & 8.380 & 7.290 & 7.360 & 7.190 & 30.220 & 12.090 \\
Rataan & $1.680^{\text {tn }}$ & $1.460^{\text {tn }}$ & $1.470^{\text {tn }}$ & $1.440^{\text {tn }}$ & 6.040 & 2.420 \\
\hline
\end{tabular}

Dari tabel diatas terlihat bahwa rataan konversi ransum burung puyuh selama penelitian sebesar 2.420. Konversi ransum tertinggi terdapat pada perlakuan KO (tanpa penambahan tepung daun katuk) yaitu sebesar 1.680 dan konversi ransum terendah terdapat pada perlakuan K3 (penambahan tepung daun katuk sebanyak 7,5\%) yaitu sebesar 1.440. Konversi ransum memberikan penilaian terhadap efisien penggunaan ransum oleh burung puyuh dengan adanya pertambahaan bobot badan yang baik.

Berdasarkan tabel diatas dapat dilihat bahwa pemberian level tepung daun katuk memberi pengaruh tidak nyata. Pengaruh tidak nyata ini di dapat karena disebabkan oleh kandungan energi yang terdapat didalam ransum pada setiap perlakuan disusun hampir sama sehingga menyebabkan pengaruh yang tidak berbeda nyata, seperti yang dikatakan Anggorodi (1985) menyatakan bahwa pemberian ransum yang paling efesien kepada burung puyuh diperoleh bila ransum mengandung perbandingan mineral yang terdapat zat-zat makanan lainnya yang diperlukan untuk pertumbuhan yang diinginkan. Kadar mineral dalam ransum menentukan banyaknya ransum yang dikonsumsi, bila burung puyuh sedang dalam masa pertumbuhan diberi ransum cukup mengandung zat-zat makanan maka burung puyuh akan mengkonsumsi ransum untuk memperoleh jumlah pengambilan gizi yang tetap perharinya. Kadar serat kasar yang tinggi akan menurunkan nilai daya cerna makanan, dapat menurunkan pertambahan bobot badan dan untuk menurunkan efesiensi penggunaan ransum.

Sedangkan menurut Zubaidah (2001) unggas cendrung memilih ransum yang berpartikel kasar dengan ransum yang berpartikel berabu. Pakan yang menarik atau palatabilitasnya tinggi akan mengalami pencernaan yang lebih baik dan sudah tentu menghasilkan konversi yang lebih baik. Dan menurut Wahyu. J.(1988)semakin baik mutu ransum maka angka konversi semakin kecil.Baik tidaknya mutu ransum dapat ditentukan oleh keseimbangan zat-zat makanan yang terkandung dalam pakan. 


\section{KESIMPULAN}

Pemberian tepung daun katuk dalam ransum burung puyuh sampai level $7.5 \%$ umur 0-8 minggu dapat menaikkan pertambahan bobot badan. Pemberian tepung daun katuk dalam ransum burung puyuh berpengaruh nyata terhadap konsumsi ransum namun tidak berpengaruh nyata terhadap pertambahan bobot badan dan konversi ransum.

\section{DAFTAR PUSTAKA}

Anonim , 2007. Manfaat dan Efek Samping Daun Katuk. Penerba Swadaya. Jakarta

Anggorodi .H.R. 1979.Ilmu Makanan Ternak Umum.Gramedia Jakarta.

Anggorodi, R. 1994.Ilmu Makanan Ternak Umum.Gramedia Jakarta.

Anggorodi, 1995,Nutrisi Aneka Ternak Unggas, Gramedia Pustaka Utama:Jakarta

Arora, S.P 1989. Pencegahan Mikroba Pada Ternak Ruminaansia. Gadjahmada University Press. Ygyakarta.

Bidura,candrawatidan sumardani, 2007.Pengaruh Penggunaan Daun Katuk (Saurupus Androgynus) dalam Ransum Terhadap Penampilan Ayam Broiler. Penerba Swadaya.Jakarta

Campbell, 1990,The Science Ofanimal that Serve Mandkind,New Delhi.

Church, D, C., and W.G. Pond .Basic Animal Nutrition and Feeding.3 th Edition.Jho Wiley and Sons., New York.

Ellydan Kinanti.1992.PuyuhTata Laksana Budi Secara Komersial.PenerbaSwadaya. Jakarta.

Hardjosworo, PD. Dan Levine J.M. 1987. Pengembangan Peternakan di Indonesia. Yayasan Obor Indonesia.

Ichwan, 2003,Membuat Ayam Pedaging, PT.Agromedia Pustaka: Jakarta

Gellips. J.R. 1987. Animal Nutrisi And Feeding. Reston. Book Prentice. United States Of America

Maynard. L.A.K. Lously. H.F.Hand. R.G. Warner 1987. Animal Nutrisi. $7^{\text {th }}$ Ed. Graw Hill Publishing Co.Ltd.New Delhi.

Mulyana. 1995. Siput Murbai Pengendalian Dan Manfaatnya. Kanisius Yogyakarta

NRC, 1995. Nutrient Requirement of Domestic Animals No. 1 Nutrient Requirements of Poultry $7^{\text {th }}$ Cd. 1977 NAS.NRC.Washington DC.

NRC, 1984.Nutrient Requirement of Poultry, National Academy of Sience.Washington DC. 
North .M.O. 1984. Comersial Chichen Production Manual .2 ${ }^{\text {nd }}$ coi .Av1 rublishing Cowestport. Connecticut.

Nugraha, 2008. Respon Penggunaan Tepung Daun Katuk Dalam Ransum Terhadap Bobot Badan Burung Puyuh.Penerba Swadaya.Jakarta

Pitijoe. 1996. Petunjuk Pengendalian Keong Mas Dan Pemanfaatan Keong Mas. Konesius. Connecticus

Rasyaf. M. 1990. Bahan Makanan Unggas di Indonesia. Kanisius Yogyakarta.

Rasyaf.M. 2002. Beternak Ayam Petelur.Penebar Swadaya :Jakarta.

Rasyaf. M. 1997. Beternak Ayam Pedaging. Penebar Swadaya. jakarta

Santoso, 2010.Penggunaan Tepung Daun Katuk (Sauropus Androgynus.) DalamRansum Terhadap Bobot Badan Burung Puyuh.Penerba Swadaya.Jakarta

Siregar, 2009, Teknik Beternak Ayam Pedaging, Indonesia Margie Grup:Jakarta.

Sinaga. H. 1998. Pengaruh Frekuensi Pemberian Ransum Terhadap Performans Itik Peking Pada Fase Glower Hingga Finisher. Skripsi Fakultas Pertanian Jurusan Peternakan USU. Medan

Steel. R.G.D. And Torrie. J.H. Priciples And Procedures Of Statisties. Mc. Grow. Hill Book Co. Inc. Newyork

Soeharsono. 1976. B. 1996. Bahan Makanan Unggas Di Indonesia. Kanisius Yogyakarta.

Tillman.H. A.D.H.1991. Ilmu Makanan Ternak Dasar. Skripsi Fakultas Peternakan Universitas Gajah Mada Press. Yogyakarta

Wahyu. J. 1992 .Ilmu Nutrisi Unggas Itik.GajahMadah University .Press.Yogyakarta.

Wahyu.J . 1997. Ilmu Nutrisi Ternak Unggas, UGM: Jogjakarta.

Wijono, 2004. Isolasi Dan Identifikasi Asam Fenolatpada Daun Katuk. Penerba Swadaya.Jakarta

Zubaidah. 2001. Pengaruh Jenis Subtract Dan Level EM 4 Pada Pembuatan Bokashi Pakan Ternak Terhadap Perubahan Kandungan Serat Kering Protein Dan Serat Kasar. Skripsi Fakultas Peternakan Universitas Andalas . Padang 